\title{
Seeking Common Ground: A History of Labor and Blue Cross
}

\author{
Gerald Markowitz and David Rosner \\ City University of New York
}

\begin{abstract}
In recent years, voluntary health insurance costs have become a major source of friction in labor-management negotiations. What was once a "fringe" has led to job actions, strikes, and intensive bargaining. We examine the history of labor's participation in New York Blue Cross from the 1930s to the recent past and show that labor's participation in the plan was crucial to Blue Cross's success in the plan's early decades. By the late 1950s, serious tensions developed over rate increases and the participation of labor in Blue Cross governance. Ultimately, the issue was one of the control over what was provided by the plans and who would pay for the costs of care. We posit that labor was never able to achieve an important role in the control of the thirdparty payer, and in the antilabor environment of the 1980s this proved detrimental to labor's interests.
\end{abstract}

The history of Blue Cross may be presented as the story of administrators, planners, and physicians. Yet this history also reflects the rapidly changing social, political, intellectual, and medical environment of New York City. In the early 1900s New York City's labor and immigrant communities had developed an uneven patchwork of fraternal, union, and commercial health insurance plans. Although they provided a measure of protection, the instability and inadequacy of these self-administered and small-scale insurance systems had become evident by the Great Depression. Blue Cross was organized in 1935 by the United Hospital Fund and the voluntary hospitals of the city and its success was due in part to its role in addressing the needs of the city's laboring population.

By the end of the Depression large numbers of the city's residents were using the hospital for births, illness, and death. The hospital was becoming an increasingly central component of "good" health care, and this development provided legitimacy to Blue Cross's role as a hospital insurance

We would like to thank Dan Fox, David Willis, Rosemary Stevens, and Robert Padgug for their comments on earlier drafts of this paper.

Journal of Health Politics, Policy and Law, Vol. 16, No. 4, Winter 1991. Copyright (C) 1991 by Duke University. 
and financing system. ${ }^{1}$ In the course of World War II, hundreds of thousands of soldiers received medical care financed and organized by a third party (i.e., the government). On the home front, government decisions spurred labor unions to bargain for third-party insurance. During the postwar era, millions of workers and their families joined Blue Cross and made it the dominant force in New York's hospital finance system.

Yet, the very success of Blue Cross in attaining its dominant position as an intermediary between union members and the hospitals created new tensions that reached a climax in 1960 with the publication of the famous Trussell Report. As a result of reforms suggested in that report, and of long-term changes during the 1960s, New York's labor unions developed a more prominent voice within Blue Cross as the organization was incorporated into new state and federal planning, regulatory, and financing systems. By the 1980s, unions struck to prevent the loss of medical benefits.

In this paper, we will first trace the ways workers and their families provided health services for themselves in the years preceding the development of Blue Cross in 1935. Second, we will outline the growing involvement of labor in the development of New York's Blue Cross in the twenty years during and following World War II. ${ }^{2}$ Finally, we will examine the developing crisis in the labor-Blue Cross relationship and discuss how it was addressed and partially resolved by the Trussell Report.

\section{Immigrants and health insurance}

Throughout the first half of this century a large portion of New York City's working class was composed of immigrants who had developed fraternal societies that provided a variety of health and welfare plans. A few local unions also developed health and welfare plans in order to provide direct service to their membership. These fraternal and union plans were a response to the fact that the very life of working-class communities was shaped by the reality of accidents, disease, disability, and death. In the early twentieth century, increases in productivity were often paid for in shorter lives, greater physical suffering, and increased dependence and hardship for family members and communities (Montgomery 1987: 192). ${ }^{3}$

1. During the Depression, discussions over the need for a more systematized nonprofit or governmental mechanism for financing hospital services reflected growing popular and professional faith in the dissemination of medical advances through "regional hierarchies." See Fox 1986; Stevens 1989.

2. The system of insurance coverage is even more complex than we have described here. For example, Blue Cross is a hospital insurance system paying solely for the "hotel" costs of a patient's hospital stay: bed, nursing, operating room, and other expenses. It does not pay for doctors' services and an entirely different insurance system covers most of the physicians' charges in the hospital, under such insurance companies as Blue Shield, Group Health Insurance, Aetna, and others.

3. As David Montgomery (1987) points out, "If employers thought of the pace of work 
Many immigrant workers, especially in New York City, developed extensive, if inadequate, methods to alleviate some of the harshest consequences of dependence caused by unemployment, injury, death, old age, and illness. Thousands of sick and benevolent societies, fraternal lodges, and Landsmannschaft groups developed in New York City between the $1880 \mathrm{~s}$ and 1920s in response to the harsh realities of urban and industrial life (Kalet, quoted in Sydenstricker 1917: 142). The extent and adequacy of coverage for working populations is unknown (Sydenstricker 1917: 442) ${ }^{4}$ But it was asserted by contemporaries that "a large number and a variety of collective efforts have been made by the wage earners themselves to provide against sickness" (Sydenstricker 1917: 469). ${ }^{5}$ A few local unions in New York and other large cities developed health and welfare plans that sought to address the devastating effects of illness, accidents, and death in the life of their members. They reached a relatively small number of workers, since only union members were eligible for coverage. They rarely, if ever, provided for hospital benefits since, at that time, the home or doctor's office was the locus of most care.

By and large, three major problems plagued many fraternal and union health plans. First, few plans were organized with any real sense of the demands that would be placed on the system. Generally, reserves were in-

\footnotetext{
in terms of the quantity and quality of their factories' output, workers thought of it in terms of their own health and longevity. ... All [workers] knew that after the average man passed his mid-thirties, the amount of working time he lost to sickness and injuries rose sharply. Employers could always find new workers, but each worker had only one body and one life" (p. 137). Disease and death took an enormous toll on families as "many women found themselves widows or keepers of invalid husbands by their forties and fifties and were driven to become wage-earners once more" (pp. 15, 16). Even skilled workers were old at forty despite their relative autonomy at the workplace. Jewish clothing workers struck in 1910, before the famous Triangle Shirtwaist fire, demanding a sanitary commission to inspect garment shops. German bakers, suffering from "bakers' disease" demanded that every loaf of bread bear a bakers' union label so that consumers would know that it was baked under hygienic conditions. Consumer groups pushed for unionization of bakers and garment workers in order to control unhygienic conditions seen as a source for tuberculosis among the industrial and middle-class population of the city. "A Strike for Clean Bread" (Survey 1910); "Investigations Have Disclosed the Fact That Unhealthy and Poisonous Bread Is Made in Non-Union Bake Shops" (Woman's Label League Journal 1913). See also Rosner and Markowitz 1985: 507-21; and, for other work detailing the concerns of workers in safety and health in the twentieth century, Markowitz and Rosner 1987.

4. See Trauner 1977 for a detailed discussion of the centrality of the fraternal societies in the development of prepaid care in that city. See Kalet, quoted in Sydenstricker 1917: $142-53$, for a discussion of the extent and inadequacy of the existing plans.

5. Sydenstricker (1917) pointed out the difficulty of establishing accurate data on the overall importance of the fraternal and union plans and noted that few studies had been conducted to determine their adequacy. But he believed that existing data suggested that the percentage of workers who had some form of health insurance was large (pp. 43234).
} 
adequate because most of the fraternal and union funds sought to keep direct costs to members extremely low (Stevens 1985). ${ }^{6}$ Second, women and children were often excluded and, for the great masses of low-wage workers, premiums even in the low-cost fraternal plans were prohibitive (Sydenstricker 1917: 471). Third, the plans that grew in the city were restricted in the breadth of their coverage. Most plans provided a very limited cash benefit that was meant to defray the costs of funerals, drugs, doctors' bills, or hospital care. Yet, few fraternal or union groups could provide more than a small percentage of the real costs of an illness as families found themselves without income to pay rent, clothing, food, and other bills. The cash benefits were paid for relatively brief periods of time and there were often exclusions in the policies for nonindustrial accidents and hospitalization (Sydenstricker 1917: 467-472).

In the absence of any government insurance and with only a few proprietary alternatives to look toward, communities of immigrants were thrown on their own meager resources to provide themselves with protection. One of the few systematic studies of these organizations revealed that fourteen fraternal societies and eleven trade unions provided nearly 125,000 persons with some form of health insurance (Kalet, quoted in Sydenstricker 1917: 143). ${ }^{7}$ In New York the importance of immigrants' use of fraternal societies was especially great. Among some ethnic groups membership was nearly universal. "It is interesting to note ... that nearly all of the Slav families carried insurance in their racial fraternal organizations which had sick-benefit features, while most of the native-born workers who were insured had policies in commercial companies which provided for only life and accident insurance" (Sydenstricker 1917: 434). The significance of the different patterns of insurance between immigrants and the native-born population was that the immigrant groups would ultimately form the membership of Blue Cross. As the hospital became an integral part of people's lives, hospital insurance would be as necessary as the older medical plans. ${ }^{8}$

6. This is an interesting discussion of the fate of fraternal organizations. We thank Jim Maxwell and Peggy Randall for providing us with this reference.

7. In other studies of other communities, it was found during the early decades of the century that upward of 60 percent of workers had health insurance plans through either unions or lodges. Death benefit societies were formed through a multitude of immigrant organizations. "It is probably true that a large proportion of the workers of the newer immigrant groups are insured in agencies and organizations providing health insurance than native and older immigrant workers," one observer noted. "This . . appears to be due to the fact that immigrant fraternal and beneficial societies are closely connected with religious and racial organizations . . which exercise a considerable influence for religious and racial solidarity." (Sydenstricker 1917: 433-34).

8. In the coming years, political organizations such as the Socialist party and, in the 1930s, the Communist party as well would also support death and sickness plans for their 


\section{The original two parties to the health and welfare debate}

The provision of health and welfare benefits was an important source of conflict between labor and management. Corporations often would provide benefits to win the allegiance of the work force itself. Beginning in the early nineteenth century, paternalist textile mill owners in Lowell, Massachusetts, initiated what became known as the Lowell Plan, in which young girls recruited from the countryside to work in the mills were provided with dormitory housing, religious training, and community services (Dublin 1979). Later in the century, other corporations, most notably railroads, and logging and mining companies, contracted with physicians to provide minimal health services to workers. In 1868 , for example, the Southern Pacific Railroad established a major industrial medical care prepayment program that continued in existence for nearly a century. In the West in 1887, the Homestake Mining Company of Lead, South Dakota, established a company-run clinic and hospital. And in the South, the Tennessee Coal, Iron, and Railroad Company in Birmingham established a health department to provide a variety of medical services to employees and their dependents. At the beginning of this century, such management practices were expanded and developed by large national corporations such as International Harvester, which sought to develop a broad health and welfare program (Berkowitz and McQuaid 1980).

Management portrayed its various health and welfare programs as a paternalist response to the felt needs of the work force. But most union representatives saw them as tools for undermining worker and trade union solidarity (Asher 1987). Management-initiated programs were seen as attempts to make workers dependent upon the goodwill of the company, thereby creating a nonmilitant, acquiescent labor force. At best, workers saw the programs as inadequate and temporary. At worst, they were perceived as tools in management's attempts to cover up the dangers of the workplace and to hide deaths or disability caused by unsafe and unclean working environments. Because of the distrust of management's motivations, workers and unions themselves organized health and benefit societies, self-insurance programs, disability compensation, old-age pensions, and even clinics and hospitals (Derickson 1988). In the nineteenth century, a wide range of mutual aid and benevolent societies developed. For example, in 1877, the Granite Cutters Union set up the first national union

members. Some of these groups, such as the Workmen's Circle, closely affiliated with the Socialists, are still around today. The Communist party supported the International Workers' Order, which broke off from the Workmen's Circle in 1931. The Circle was forced out of existence by the New York State Insurance Department in the early 1950s because of its earlier affiliation with the Communist party. 
sick-benefit program. Founded in 1887 , the Barbers Union organized a sick-benefit system in 1895 . The Tobacco Workers Union was established in 1895 and developed a sick-benefit program a year later (Klem and McKiever 1953).

By the mid-twentieth century, there were well over two hundred group health plans in the country. Of these, two-thirds were organized through specific industries either by employers, employees, or joint action (Klem 1944: 117). Among the more important employee-sponsored plans were the Hospital and Medical Care Program of the United Mine Workers of America Welfare and Retirement Fund; the Labor Health Institute of Saint Louis (Local 688, International Brotherhood of Teamsters, the American Federation of Labor [AFL]); the Health Institute of the United Auto Workers, Congress of Industrial Organizations (CIO), Detroit; the Union Health Center, International Ladies' Garment Workers Union (ILGWU), AFL, Boston; the AFL Medical Service Plan of Philadelphia; and the Sidney Hillman Medical Center of the Male Apparel Industry of Philadelphia (Amalgamated Clothing Workers, ClO) (Klem and McKiever 1953). All these programs, especially those affiliated with the United Mine Workers, the ILGWU, and the Amalgamated, grew out of labor's interest in providing their members with alternatives to management-sponsored health programs. In New York City, unions followed a similar pattern of health center organization. The ILGWU, a union organized and led by skilled immigrant workers, and born out of early twentieth-century struggles over wages and hours and workplace safety and health, organized its own health clinic as early as 1913. But other unions, most notably the Hotel Trades Council and the Amalgamated Clothing Workers, a union with a long socialist tradition, organized their clinic and health plans in the early 1950s.

The 1930s are a critical period for understanding labor's changing attitude toward union-controlled health and welfare programs. During this time, under the financial pressures of the Depression and a growing accord with the New Deal administration in Washington, labor considered new models for the provision of health and welfare services to its members. Beginning during the Depression and especially after World War II, many of the fraternal organizations began to decline, as ethnic identification and immigrant ties to particular neighborhoods and communities loosened. As assimilation proceeded and unions assumed a greater role in the lives of New York's working population, local unions saw insurance as a mechanism for protecting its members and for strengthening the relationship between members and their locals. In the 1940s and 1950s company- and union-sponsored plans increased, but the major movement was toward nonprofit third-party insurance.

During the Depression, organized labor faced innumerable problems as millions of its workers found themselves unemployed and dependent. Also, 
the long-standing supremacy of the American Federation of Labor was challenged by the organizing drives in heavy industry spurred by the Congress of Industrial Organizations. With the development of the $\mathrm{CIO}$ in the second half of the decade, organized labor faced an internal split in its ranks. For the first time in labor history, significant sectors of organized labor looked to the national government for support, protection, and advice. In the context of the Depression, as the new CIO became deeply involved in organizing millions of workers, significant portions of the labor movement supported governmental programs in the area of social welfare, protective legislation, and even hours and wages. Walter Reuther and the United Auto Workers (UAW), along with other leaders of the CIO, even went so far as to endorse various calls for national health insurance. ${ }^{9}$ At its first national convention in 1938 the CIO supported "a national health program" (Starr 1982: 304). This was a dramatic break with the traditions of the AFL, which saw national health insurance as a threat to the welfare funds numerous locals had built up over the years. The CIO leadership in heavy industry accepted the notion of outside control of health and welfare benefits, while the AFL insisted on control over its financing.

Blue Cross and the labor movement. Organized labor showed a growing interest in Blue Cross in the 1930s and 1940s because it could be incorporated into both the local AFL craft union welfare structure as well as the national $\mathrm{CIO}$ collective bargaining agreements. The AFL welfare funds could purchase services from Blue Cross without giving up its autonomy and the CIO could bargain with the steel and auto industries for management to buy service plans. Because Blue Cross was a nonprofit serv-

9. We do not see it as our mandate to detail the history of medical practice and hospital care during the 1930s. Suffice it to say, the hospitals and physicians themselves were undergoing their own internal struggles over a range of economic and political issues. During the 1930s, the long-standing opposition of the American Medical Association (AMA) to group practice, national and compulsory health insurance, and "contract" practice intensified, and those advocating such programs were often accused of sponsoring "socialized" medicine. In all of its actions, the AMA sought to protect the autonomy of the practicing physician. The hospital community at this time was struggling through its own financial crisis as demand increased and income dwindled. Within this context, the first Blue Cross and Blue Shield plans were organized and they incorporated the concerns of the professionals who backed them. Blue Cross and Blue Shield promised a way out of the hospitals' and doctors' dilemma for, while providing a stable source of income to their members, they neither depended on government nor, in the words of the medical community of the 1930 s, "sacrificed the autonomy" of the doctors.

On the local level, the medical community was involved in a number of parallel efforts to counter the growth of group practice and calls for national health insurance. But it was also involved in gaining a greater say in a program of direct interest to labor: the administration of workers' compensation. It was here that labor and medicine had their most intense and involved relationship and where the first overtures from the medical community to labor first developed. 
ice plan rather than a commercial profit-making indemnity plan, it was distanced from labor's long-standing distrust of commercial plans suspected of profiteering from the misery of workers and their families (Shurtleff and Cohan 1989). Blue Cross was also attractive because it paid for services in hospitals as they were emerging as a central source of health care for millions of Americans. Therefore, Blue Cross was seen as a "community" plan that addressed pressing community needs without taking sides in the heated labor-management conflicts of the Depression and postwar period. ${ }^{10}$

The special circumstances of World War II helped Blue Cross to grow. According to a 1943 Internal Revenue Service ruling, fringe benefits were not considered income and were therefore not subject to the wage freeze. For businesses, furthermore, "legitimate insurance plans for employees could be deducted from gross income as a proper business expense," which "stimulated the growth of union health and welfare programs under collective bargaining" (Klem and McKiever 1953: 7). In addition, war industries were reimbursed by the government on the basis of their total costs plus a percentage for profit. Thus, if a company paid for its employees' hospital and medical insurance, not only was the entire cost of that program passed along to the government but the actual profit to the company was increased as well (Mannix n.d.).

During the postwar years, "the general shift in American labor relations from conflict to accommodation" (Starr 1982: 313) helped to solidify the importance of Blue Cross to both unions and management alike. A government study conducted in October 1947 found that 1,250,000 were covered by collective bargaining agreements providing hospital protection or other health benefits and that this represented a doubling between 1945 and 1947 (Reed 1947: 66-67). Paul Starr (1982) documents that "between 1948 and 1950 the number of workers covered by negotiated health plans jumped from 2.7 to more than 7 million. By the end of 1954,12 million workers and 17 million dependents were enrolled in collectively bargained health plans." He further notes that by 1954 "over 60 percent of the population had some type of hospital insurance" (p. 313).

Blue Cross in New York. If the national situation appeared to augur well for Blue Cross's future, the situation in New York City was even rosier. Unlike other cities, such as Detroit, Akron, or Pittsburgh, which were dominated by one or two industries - auto manufacturing, steel production, or

10. Before the development of Blue Cross programs, there was no third-party alternative for labor other than commercial insurance, which unions were wary of because of their antagonistic encounters with insurance carriers in Workman's Compensation proceedings. 
rubber, for example-New York was composed primarily of light manufacturing and service work. New York was a strong union town, but it had many unions of diverse political orientation. Despite appearances of solidarity on many common issues, deep antagonisms existed among socialist, communist, liberal, and conservative labor leaders. Also, ethnic differences tied in with the fractious political scene in New York to complicate unified organizing efforts among workers dispersed in a wide variety of small, mostly isolated worksites. Garment workers, construction workers, department store workers, cigar makers, and furniture makers, all worked in sites spread widely throughout the five boroughs. New York's labor unions were dynamic, complex, and highly contentious (Faggen 1989).

It was during this period of labor unrest and economic dislocation that Blue Cross was first organized. During the Depression, the inability of patients to pay for their hospital care had forced many institutions to shut down or curtail services. In response to this crisis, the United Hospital Fund organized this nonprofit insurance plan as a means of providing hospitals with needed funds and patients with the security of knowing that, in case of sickness, their hospital costs would be covered. Its early advertising boasted that for "pennies a day" New Yorkers could be protected from the insecurity caused by the costs associated with illness. Originally calling its insurance plan the " 3 cents a day plan," Blue Cross began signing up members individually. But within a few months it approached business to sign up "groups" of workers through a payroll deduction plan.

From the perspective of labor, Blue Cross was a dramatic improvement over the commercial carriers who were at that time a major competitor. Some unions documented collusion between commercial carriers and management. Companies would charge workers for their health insurance at the full rate and then, at the end of the year, receive a "dividend" from the commercial carrier for every worker covered. In essence, management received a kick-back, which came out of the workers' pockets, for signing onto a commercial plan (Shurtleff and Cohan 1989). From the very start, Blue Cross promised the labor movement a nonprofit, centrally organized administrative mechanism that would provide union workers with a needed service.

The apparent concordance of interest between labor and Blue Cross veiled some social tensions and political differences. In the early years, labor and Blue Cross leaders were drawn from different social groups. These differing ethnic, class, and political party alignments were sources of friction, ${ }^{11}$ as early efforts by Blue Cross to win labor support for the

11. Harold Faggen, an accountant and lawyer who worked closely with some of the unions in the 1950s, was more pointed in his comments about the social origins of Blue 
plan reflect. During World War II, leaders of the Congress of Industrial Organizations began a dialogue with Blue Cross about the differing perspectives of labor and Blue Cross. In March 1943, Saul Mills, secretary of the Greater New York Industrial Union Council, Congress of Industrial Organizations, which represented most of the left-wing unions in the city, wrote to Louis Pink, former insurance commissioner of New York State and then president of Blue Cross of New York, complaining about the lack of progress "in meeting some of the apparent shortcomings of the [Blue Cross] plan" (Mills 1943).

Three major issues emerged that initially led the city's unions to say that "they could not now recommend adoption of [the] Blue Cross plan" to their membership. The first major issue was the lack of accountability of Blue Cross to the unions. The board of directors of Blue Cross was "composed predominantly of hospital and medical" people and lacked labor representation. They contended that labor could not endorse a plan when it had no voice in the management or control of the plan. Second, they objected to Blue Cross's identification with management. Blue Cross, seeking to increase membership, had originally appealed to employers, suggesting that adoption of the Blue Cross contract "cost them nothing" because of the payroll deduction plan. Labor complained that while management got credit for providing a health plan for its members, labor, not management, was footing the bill. Blue Cross, in contrast, was wary of allowing too much power to slip into the hands of labor. Louis Pink responded to the union demand for board membership by stating that "there were no vacancies on the Board at present." He proposed instead a labor advisory committee (Conference Notes 1943).

Despite their differences, Blue Cross and the unions were able to reach a compromise that paved the way for greater participation of labor in Blue Cross. Within a year, Elinor Herrick, regional director of the National Labor Relations Board, joined the board for one year. A year later, John D. Connors, from the Department of Education, American Federation of Labor, and Saul Mills himself were invited to join the board. Even so, these two labor representatives were but a small voice on the twenty-five-member board, one half of whom were hospital administrators, trustees, and doctors, and the other half industry representatives, consumer groups, and public officials. Several left-wing unions, nearly all of whom were affiliated with the Greater New York Industrial Union Council, joined Blue Cross in the mid-1940s as a result of these efforts. Among these were pocketbook workers; furniture workers; painters; optical workers; retail drug

Cross's leadership. He said that many in the labor movement saw "Blue Cross as a place to retire Republicans from Albany" (Faggen 1989). 
store employees (soon to emerge as representatives of the hospital workers); chefs, cooks and pastrycooks; waiters and waitresses; taxi workers; cigar workers; fur and leather workers; office and professional workers; cemetery workers; meat choppers; and others (Pink 1946). Other early recruits into the ranks of Blue Cross were the AFL Building Trades unions, especially the Carpenters Union and International Brotherhood of Electrical Workers (Shurtleff and Cohan 1989).

These initiatives led to an enormous expansion of union involvement in Blue Cross during the last year of the war and during the postwar years. During the last year of the war, from September 1944 through September 1945 , over 340 collective bargaining agreements provided over 175,000 workers and their families protection. One early government study concluded prophetically that "the development of union health and welfare programs may well have an important effect upon the future growth of Blue Cross plans" (Reed 1947: 67). The event that cemented the bond between Blue Cross and the unions was the decision in 1946 by the municipal government to pay for half "the total cost of ... [medical and] hospital care for municipal employees who elect to enroll in [the Health Insurance Plan and] . . Blue Cross" (New York Times 1947). By mid-1946, Blue Cross estimated that 550,000 employees and their dependents were covered for hospitalization in New York City. This was about one-fifth of its total subscribers (Pink 1946).

It is difficult to overstate the importance of the growth in union membership and the municipal decision to supply Blue Cross insurance to its employees. Between 1939 and 1943, the annual increase in premiums to Blue Cross was never more than 4 percent. Yet, following the Internal Revenue Service decision not to consider fringe benefits as income and the involvement of the Greater New York Industrial Union Council to provide its members with benefits, the annual increase in net premiums grew dramatically. In the years 1944,1945 , and 1946, the annual increase in premiums rose 17 percent, 27 percent, and 28 percent, respectively. The most dramatic rise followed New York City's decision to provide Blue Cross as a fringe to its employees. Between 1946 and 1947, premiums rose 47.4 percent, the largest percentage increase in the post-Depression era (Associated Hospital Service n.d.).

Growing interdependency of labor and Blue Cross. Documents from the Blue Cross archives indicate the tremendous attention paid to administrative and organizational detail in these early years. Through the working out of this detail Blue Cross and the unions became interdependent. One example is the case of the Pocketbook Workers Union and their negotiations with Blue Cross regarding the collection of members' fees. In 1946, the executive director of the union wrote Louis Pink a detailed memo ex- 
plaining the problems that his workers would face in subscribing to Blue Cross through a payroll deduction scheme. He specifically noted that his membership, like that of many of New York's unions, was not highly concentrated in one or even a few large plants. Rather, his union represented workers who were scattered throughout the city. The members worked in plants, warehouses, sweatshops, and lofts, many of them "employing less than [ten] workers" (Wolinsky 1946). Only a limited number of shops employed more than one hundred workers. The problems in administering benefit programs for his union members were numerous, especially when the protection under the Blue Cross plan depended upon unreliable small businessmen who failed to pay the premiums necessary to maintain employees' benefits. Few of these shops, Wolinsky held, had the capabilities to maintain up-to-date records of employment and coverage. He suggested that any success was really a product of the degree of union control over administration and that such control should be increased (Wolinsky 1946) ${ }^{12}$ From labor's point of view, central administration of benefits should come through the union itself in order to protect workers from inefficient, uncaring, and sometimes dishonest businessmen. In New York, the centralized, bureaucratic nature of Blue Cross had a special appeal to the city's union leaders, who found daunting the prospect of administering hospitalization plans for thousands of workers dispersed throughout dozens of shops in the various boroughs. Furthermore, Blue Cross sought to accommodate the needs of the numerous small locals scattered throughout the city. They allowed individual locals to join with others to qualify for lower retention rates and discounts, as well as to certify which of their individual workers were qualified to receive coverage (Shurtleff and Cohan 1989).

The expansion of Blue Cross occurred within the context of massive political upheavals within New York's labor and liberal establishments. During the last years of the Depression and World War II, the American Labor party emerged as a powerful force in New York City. It was originally organized in 1936 "by leaders of New York's heavily Jewish garment trades to provide a mechanism for supporting Franklin Roosevelt and Fiorello LaGuardia," the charismatic fusion reform mayor (Shefter 1986). The party was a coalition of left-wing and liberal politicians and unions. Despite its relatively small membership, the party's importance in local politics can be measured by the fact that LaGuardia's margins of victory in 1937 and 1941 were by votes cast on the American Labor party line. After World War II, the New Deal coalition between liberals and the Left dissolved.

12. Wolinsky noted that "the hospitalization service is represented right in our office" and "the records of all shop employees are constantly being checked as against the union membership on our records." 
Liberal labor leaders such as David Dubinsky, president of the International Ladies' Garment Workers Union, and Alex Rose, president of the Hat, Cap, and Milliners Union, bolted from the American Labor party, charging that it was dominated and controlled by the American Communist party. In its stead, these important New York labor leaders organized the Liberal party, which had a major political impact on city politics and became tied to the anti-communist labor movement in the city. In contrast to the American Labor party, which had been organized around Italian, Jewish, and black political clubs in the city, the Liberals were much more centrally controlled and appealed primarily to the Jewish trade unions and middle class. ${ }^{13}$ These changes, together with the passage of the Taft-Hartley Act in 1947, moved the mainstream of the union movement in New York farther to the center. The political warfare among New York's labor unions made Blue Cross's organized, bureaucratic structure all the more attractive, taking fringe benefits out of the contentious arena of union politics. In the words of one observer, "In place of precedents, we are now watching a parade . . . a mass migration" of unions into Blue Cross (Tilove [1950]).

Growing tensions. By the mid-1950s Blue Cross was the organization of choice for the majority of the city's unions (Shurtleff and Cohan 1989). ${ }^{14}$ But, in the late 1950s, Blue Cross's requests for rate increases brought to the fore tensions between labor and Blue Cross. The ostensible immediate issue was that Blue Cross premium increases would take too large a bite out of the workers' fringe benefit package. Some labor representatives argued that Blue Cross was maintaining too large a reserve fund; others argued that Blue Cross failed to represent union interests and hold down hospital costs; still others maintained that unions could save money by insuring their own members. But the common complaint among union leaders was that despite the nominal labor voice, the Blue Cross board was still unrepresentative of the population that Blue Cross served.

One indication that some of the unions were unhappy with Blue Cross was the decision by the Furniture Workers Union in the mid-1950s to leave Blue Cross and insure its own members (Faggen 1989). ${ }^{15}$ But the warning

13. See Shefter 1986 for a fascinating and detailed account of the politics of New York City in the postwar period.

14. Shurtleff and Cohan (1989) estimated that between 50 and 70 percent of New York's organized labor force belonged to Blue Cross by the late $1950 \mathrm{~s}$ and that 72 percent of the unions had joined by the mid-1970s.

15. Harold Faggen, an accountant who consulted with a number of unions and helped the Furniture Workers Union to set up its self-insurance fund, was a spokesperson for the self-insurance movement. His counterpart, Martin Segal, was an accountant for a number of other unions and advocated staying within Blue Cross, while pressing for greater representation and benefits. 
of the more general crisis in union-Blue Cross relations came in 1956 at a meeting sponsored by the Central Trades and Labor Council and the Greater New York Fund. At this time, a lone voice, the left-wing leaders of District 65 of the United Auto Workers, called on unions to pay greater attention to what they considered the huge reserves held by Blue Cross ( New York Times 1956). New York's labor movement put aside its factionalism to take issue with Blue Cross the next year. In the fall of 1957, when Blue Cross asked the insurance commissioner of New York State to approve a 40 percent rise in the rates charged its members, the New York Times proclaimed: "City and Labor Are against It, Hospitals in Favor" (New York Times 1957b).

In this early skirmish between labor and Blue Cross two major themes emerged in the arguments against a rate increase. First, union representatives argued that the "crisis" in Blue Cross's financing was a technical accounting problem that could be simply addressed by reorganizing the books. At that time Blue Cross was required by the state to maintain a 25 percent reserve fund. Labor pressed for the reduction of that reserve fund rather than a rate increase, because, in the words of an official of the Office and Professional Workers Union, they believed that "the annual increase in premiums would devastate us, and affect our ability to bargain for higher wages" (Shurtleff and Cohan 1989). Harold Faggen argued that "by slightly altered bookkeeping Blue Cross should show a net profit of more than two million rather than a loss for the last year" (New York Times 1957a). Second, he argued that "commercial thinking and standards were creeping into Blue Cross policy making" and that Blue Cross was little more than a representative of the hospital industry's interests. Liberal representatives of the labor movement such as Walter Eisenberg, economic consultant to the Central Trades and Labor Council of Greater New York and the New York City CIO Council, suggested that "the fundamental idea underlying Blue Cross has been and should be that of a joint user and supplier vehicle for the provision of pre-paid hospital service, rather than a non-profit producer's cooperative run for the primary purpose of stabilizing an ever-larger portion of the income of the suppliers, that is, the hospitals" (New York Times 1957b). Echoing the historic concern of the AFL to control and administer health benefits, and the new centrality of health and welfare benefits to organized labor, Eisenberg demanded that Blue Cross reorganize its board so that 50 percent of its members would be drawn from labor.

This union analysis struck a responsive chord among the liberal establishment throughout the city. Michael M. Davis, a renowned elder statesman of health care policy and then chairman of the executive board of the Committee of the Nation's Health, wrote to the Times, observing that the Blue Cross governing bodies generally underrepresented the views of labor and consumers. He warned that "such policies may cause organized labor 
... to turn away from Blue Cross and seek other forms of hospitalization insurance. ... The public at large, whether Blue Cross subscribers or not, has reason to be aggrieved when Blue Cross conducts itself like a selfcontained private business, instead of an agency having the privileges and immunities of a non-profit body established to perform a public service" (New York Times 1958a). The New York Times was expanding on this theme that New York's Blue Cross was violating the public trust. In a stinging editorial published at the end of 1957, the Times argued that Blue Cross had "not given its subscribers and the public the status they should haveespecially in dealing with the hospitals as to charges." The editorial concluded by noting that only one of its directors represented organized labor and none represented the city or its employees (New York Times 1957c). ${ }^{16}$ A few months later Blue Cross, citing increased costs and the fact that its rates had not been increased since 1 May 1952, applied for an increase of about 40 percent. At a public hearing in June 1958, the now-familiar arguments were repeated (New York Times 1958b). ${ }^{17}$ Shortly thereafter, the state superintendent of insurance tried to resolve the differences between labor and Blue Cross by granting a rate increase of 22.3 percent (New York Times 1958d).

For nearly a year Blue Cross avoided requests for new rate increases and relations between it and the bulk of the New York labor movement remained stable, if uneasy. Blue Cross decided to appoint four new directors, three of whom were drawn from the ranks of organized labor. ${ }^{18}$ But this attempt to give labor a greater voice was largely offset by other changes on the board. Recognizing that a major fight with labor was brewing over Blue Cross and the role of organized labor within the hospitals themselves, the United Hospital Fund, representing sixty-six voluntary hospitals throughout the city, decided in May 1959 to exercise its statutory right to appoint twenty-one of the thirty members who elected the Blue Cross board of directors. At the board of directors meeting in June 1959, the United Hospital Fund "placed seven new members who subscribed to its views on the Blue

16. Given this kind of opposition, it's not surprising that the New York state insurance commissioner rejected Blue Cross's rate rise request at the end of January 1958.

17. See also, New York Times 1958c quoting Bernard Greenberg, an economist for the United Steel Workers of America, who spoke on behalf of the state CIO Council and the State Federation of Labor: "Labor in New York insists that Blue Cross policies must be directed away from the single-minded concern with meeting unquestionably every demand of the hospitals and toward a balanced view which impartially gives equal weight to the needs of hospitals, subscribers and the public interest."

18. The new members of the Blue Cross board were Thomas Carey, district business manager of the International Association of Machinists; Louis Hollander, vice president of the Amalgamated Clothing Workers Union; and Charles Zimmerman, a vice president of the International Ladies' Garment Workers Union. The existing member was Harold J. Garno, secretary-treasurer of the AFL-CIO. 


\section{Journal of Health Politics, Policy and Law}

Cross Board of Directors and obtained reelection for 10 backers already on the Board" (New York Times 1959b). As the New York Times (1959e) reported, "the United Hospital Fund exercised its long-unused voting control power ... to assert its right of parentage over [Blue Cross]." Simultaneous with these changes in board membership, Blue Cross decided to ask for another increase in its rates of 34.2 percent (New York Times 1959a).

In order to understand the coming storm of protest from labor and the rapidly unfolding events of the coming year, we need to take a step back and look at labor's relationship to the broader hospital industry during the late 1950s. At the very same time that the controversy over Blue Cross rate requests was unfolding one newly emerging union, Local 1199, led by Leon Davis, had begun to organize hospital workers. This organizing drive represented a fundamental change in the perception of the voluntary hospitals of the city. By the late 1950s, the hospitals were no longer viewed solely as paternalistic charity providers. Rather, labor and portions of New York's liberal establishment increasingly perceived Blue Cross to be part of the larger health care industry, a sector of the economy that sometimes made enormous profits and employed workers at substandard wages. As the perception of hospitals changed among important elements of New York's liberal and left communities, they became the focus of union-organizing drives (Fink and Greenberg 1979). In 1957, Davis began the campaign to gain recognition for his union from Montefiore Hospital. Between December 1957 and August 1958, Local 1199 signed up a majority of Montefiore's workers and in March 1959, the union negotiated its first contract with Martin Cherkasky, the head of that hospital. Shortly thereafter, 3,500 workers struck for forty-six days at the city's major voluntary hospitals. This was a bitter and prolonged strike that created deep animosities not only between Local 1199 and the voluntary hospitals but also within organized labor itself (Fink and Greenberg 1979, 1989). Privately, portions of New York's labor community opposed the strike as ill-advised and divisive, since the action was widely portrayed as a strike against patients rather than against industry. But in public, the labor movement used the strike to press its arguments against rate hikes. It was said that increased rates would be used to pay for fancy new equipment, not to better the wages of hospital workers.

The impact of the request for a rate increase at the very time of the strike cannot be overestimated (New York Times $1959 \mathrm{c}$ ). ${ }^{19}$ Bernard Greenberg,

19. One of the first labor spokesmen to give testimony at the hearings over Blue Cross rate increases in May 1979 was Leon Davis, whose hospital workers were then in the midst of a vicious and prolonged struggle with the voluntary hospitals. He demanded that the hearing be adjourned until the strike was settled. 
speaking for the New York State AFL-CIO, denounced the proposed increases as "excessive and unjustified." He linked the hearing over Blue Cross directly to the ongoing labor struggles when he said that the "increased rates given to hospitals in past years had not been reflected in higher wages for hospital workers" (New York Times 1959d). The pressure from organized labor was so great that Mayor Robert Wagner publicly opposed the rate increase. In a page 1 story, the New York Times reported that Wagner, "citing the hospital strike has come out in opposition to Blue Cross's application for rate increases." The Times continued that the mayor was upset that "only a small part of the proposed 34.2 percent increase would go to improving the distressingly low wage level of non-professional hospital workers" (New York Times 1959f) ${ }^{20}$ While the results of these hearings were generally favorable to Blue Cross and the hospital industry, the rift this created between labor and Blue Cross was profound. ${ }^{21}$ The prevalent opinion of labor leaders was that "there was a startling identity between the hospitals and Blue Cross" (New York Times 1959d). In the words of another observer, Blue Cross was emerging as "little more than a collection agency for the hospitals". (Greenberg 1961: 33).

Blue Cross's image had become linked to that of the voluntary hospital during the 1950s. During this decade the hospital was touted as "a technological and community institution with little conflict between the two goals" (Stevens 1989: 227). But as hospital costs rose and public consciousness about the unequal access to quality health care increased, this benign view of the hospital's dual functions started to fray. Blue Cross's traditional portrayal of itself as a partner in league with a benevolent community institution now took on a new meaning. Its role as a partner of the hospitals came under criticism from those who wanted it to play a more active regulatory role in holding down hospital rates. Instead, Blue Cross paid out more to the hospitals and charged higher premiums to its subscribers, maintaining its traditional stance as a passive collection agency. Blue Cross did not change its way of operating - the critics changed their expectations, because of Blue Cross's critical role in financing the hospital system. By the late 1950s this was no longer a "pennies a day" operation. Rather, it had emerged as the preeminent financial agent in the city. As such, from the unions' perspective, it had new responsibilities and obligations to control the costs of medical care to its members. Unions were pressing Blue Cross to oversee, if not manage, the costs of care to its mem-

20. In the end, Blue Cross substantially prevailed against this opposition and the state insurance commissioner granted a rise of 26.5 percent.

21. In the late 1960s hospitals and Blue Cross would become the focus of academic and activist critiques. See, e.g., Law 1974 and various publications and pamphlets of Health Policy Advisory Center (Health PAC), especially The American Health Empire (1971). 


\section{2}

\section{Journal of Health Politics, Policy and Law}

bers. Blue Cross's leaders were taken by surprise at the intensity of the anger and frustration that union groups expressed. Only a few years before, they believed, "there was mutual respect-the ability to listen to each other." In the early years of the 1950s unions believed that "Blue Cross was the best deal in town." Now it seemed that there was an enormous gulf between them (Shurtleff and Cohan 1989).

The schism had become so severe that in the fall of 1959 the labor movement in New York threatened to study the feasibility of "using pension and welfare trust funds to build and operate hospitals and insurance programs for hospital and medical care" (New York Times 1959h). Harry Van Arsdale, Jr., president of the New York City Central Labor Council, "reported that 26 major New York unions were represented in a special committee on health and hospitals authorized by the council." He directly connected the formation of this committee to the bitter struggle to form the hospital union and the displeasure with Blue Cross administration and programs. Van Arsdale said, "We have sweat shop health standards in our hospitals. They underpay their staffs and underserve their patients. Yet, we are confronted with sky-rocketing costs that must be paid out of our Welfare Funds. . . The program is under the control of big business and the hospital administrators. We intend to develop the program that will benefit all the people of the city" (New York Times 1959g).

The threat to organize an independent labor-controlled hospital system was little more than a rhetorical device to bring attention to labor's frustration. The labor movement itself was divided and this proposal had little chance of being acted upon in the highly contentious and competitive New York labor scene. But their threat to do so was not simply the result of a temporary pique. Union leaders rejected calls from the hospital and Blue Cross representatives that "we all work together on this" (New York Times 1959i).

In the midst of this controversy, the Trussell Report, a study conducted by members of Columbia University's School of Public Health to assess health planning in the state, was released. The report spoke to a number of issues that had been causing friction between labor and Blue Cross over the years. It recommended, for example, that the New York State RateSetting Commission and regional councils be broadly representative and should include hospital and medical organizations, labor, industry, and local health and welfare departments. It acknowledged that more rate rises were inevitable, both because of constantly increasing hospital costs, and because the public had been receiving care "subsidized by underpaid hospital personnel." The report went on to urge Blue Cross to "overhaul their own Board of Directors to make them more representative." It specifically suggested that "not more than half the Board members be hospital trustees, physicians, hospital administrators or other professional personnel" (New 
York Times 1960a). Ray Trussell, a professor at Columbia University, recognized the ongoing struggle between labor and the hospital industry of New York as a significant factor in shaping the health care system. Both in the report and subsequent comments, he sought to link the crisis in the health system to the crisis in labor-industry relations. In calling for a restructuring of New York's health system, he and his staff sought to provide an alternative to what was then emerging as a severe Blue Cross-labor confrontation. He sought to create the conditions that would reestablish the credibility of Blue Cross as a reasonable third party in providing health insurance to the work force as well as a partner in the mechanism to control the rising costs of the new hospital and health industry. "The survival of Blue Cross is 'entirely up to labor and industry,' according to Dr. Ray E. Trussell," reported the Times in 1960. " "They are the major decision-makers-they could pull the rug right out and then decide what other way to provide care,' he declared" (New York Times 1960b).

\section{Labor's loss of power}

Despite the rhetoric of the union movement, by the late $1950 \mathrm{~s}$, much of the control over health care had already passed to third parties-organizations and professionals outside of the traditional arena of labor-management strife. Health care in New York had, indeed, become a major industry. Federal support for medical school research, the development of health planning agencies, the provision of federal and state monies for the construction of hospitals, and a host of other changes had solidified the control that professionals, physicians, and insurance companies exerted over the system. Furthermore, the apparent successes of medical science had led many in the liberal labor community to believe that health issues were truly amenable to scientific intervention. In this context, labor had little chance to build an alternative set of institutions or develop a system of care that could bypass professionals and institutions perceived to be at the cutting edge of good health care. New York's labor movement made the decision to join Blue Cross during the 1940s and 1950s because it implicitly recognized that it had neither the resources nor the desire to develop its own institutions.

The significance of labor's involvement in the history of Blue Cross has generally been neglected. Yet, for a number of reasons, labor's history is critical. It was important because union members formed the base of Blue Cross in New York. But labor's participation in Blue Cross was not without controversy. Their stormy relationship was rooted in labor's own history and its own diverse social and political assumptions. The obvious conflicts appeared concrete, revolving around rates, comprehensiveness of services, and number of directors. Yet, underlying these issues was a desire on the 


\section{4}

part of labor to have a full voice in Blue Cross. As fringe benefits and, specifically, health insurance emerged in the post-World War II era as critical issues in management-labor negotiations, unions saw Blue Cross in a new light. While Blue Cross itself may have continued to see its role as an intermediary between consumers and the city's hospitals, labor now saw it as part of an enormous industry that was consuming labor's resources without labor's representation. Until World War II, labor and its immigrant constituents had developed their own insurance systems. They had joined Blue Cross because of its image as a community service organization during and after the war. They gave up their claim to sovereignty over health services in the belief that third parties would adequately represent labor's interests. But as hospital rates rose and Blue Cross increased its own premiums to keep pace, this quid pro quo was eroded.

In the 1960s, the unions achieved a greater voice on the Blue Cross board and found some common ground with its new leadership. Union leaders not only served on the board but also were hired to fill important positions within the Blue Cross hierarchy. More importantly, they achieved greater influence through the development of state and federal regulatory activities. The confrontation that labor created over the rate hikes in the late 1950s ushered in the profound realignments among labor, Blue Cross, and the state as voluntary and, later, regulatory agencies became the new battlegrounds in the struggles over the financing and regulation of health care. ${ }^{22}$

But, by the late 1970 s and 1980 s, what the union movement had really given up was brought into sharp relief. The labor movement, forced by antilabor federal and state policies, had to make concessions in a host of areas from wages and working conditions straight through health and retirement benefits. By the late 1980 s, it had become apparent that health benefits themselves were being eroded and that the labor movement had little ability to shape the behavior of Blue Cross or other insurance companies without resorting directly to strikes and job actions. The fact that Blue Cross had representatives of labor on its governing councils did nothing to protect labor from management decisions to undercut the scope and cost of health benefits. Strikes and labor actions increasingly focused on protecting health benefits from management-led attempts to limit health insurance benefits and costs. Despite the post-World War II accord between management and labor to support the growth of the voluntary health insurance sector, by the 1980 s, health care had, in the words of the Los Angeles Times, "become one of the stickiest issues in U.S. labor relations" (Los Angeles Times 1989).

22. During the 1960 s, it appears that Blue Cross took on a more adversarial relationship with the hospitals. See Shurtleff 1975 for information concerning a series of lawsuits between Blue Cross and the hospital industry. 
In the summer of 1989 , the real import of health benefits as a labormanagement issue was brought home by the extended strike of the various "Baby Bell" telephone companies including New York, California, and thirteen other states in the Northeast, Midwest, and West Coast. In what the Los Angeles Times headline proclaimed was a "Phone Strike Centered on Issue of Health Care," workers at NYNEX, Pacific Bell, and Bell Atlantic went out on strike over management's insistence that the unions pay a greater portion of their health care premiums (Los Angeles Times 1989). In contrast to their willingness to grant wage concessions throughout most of the 1980s, unions and their membership struck to protect what was once considered a fringe benefit. What had been a trivial cost to companies in the 1940s and 1950s had risen to 7.9 percent of payroll in 1984 and 13.6 percent by 1989 (Wall Street Journal 1989a). Unable to control the industry that had formed around hospitals, doctors, drug companies, and insurance companies, portions of the labor movement redefined its central mission: the fringes of the 1940s and 1950s were now central concerns.

It is significant that the Communication Workers of America made health care the central issue of the strike and in the final settlement was willing to sacrifice wage increases to protect health benefits (Wall Street Journal 1989b). In the words of one union local president engaged in the bitter communication workers strike: "'It took us 40 years of collective bargaining' to reach a contract in which the employer contributed all of the costs of health care, 'and now they want to go in one fell swoop backward'" (Los Angeles Times 1989).

The historical study of labor and Blue Cross gives us some distance on the growing debate over who should pay for health care costs. In large part, labor and management fueled the growth of the health industry. Yet labor has allowed the control of health care to escape them over the course of the last half century. In a more affluent era its lack of control over resources and services was obscured by rising wages and improving benefit packages; in these more stringent times the double-edged nature of those postwar decisions to give up control to third parties becomes more apparent.

\section{References}

Asher, R. 1987. The Limits of Big Business Paternalism: Relief of Injured Workers in the Years before Workmen's Compensation. In Dying for Work: Workers' Safety and Health in Twentieth-Century America, ed. D. Rosner and G. Markowitz. Bloomington: Indiana University Press.

Associated Hospital Service. n.d. Financial Data, 1935-1973. Compiled by Margaret Randall. Empire Blue Cross and Blue Shield Archives, New York.

Berkowitz, E., and K. McQuaid. 1980. Creating the Welfare State: The Political Economy of Twentieth-Century Reform. New York: Praeger. 
Conference Notes. 1943. Memorandum of Saul Mills and Martin Segal representing ClO Council, 12 April. Pink Papers, Empire Blue Cross and Blue Shield Archives, New York.

Derickson, A. 1988. Workers' Health, Workers' Democracy. Ithaca, NY: Cornell University Press.

Dublin, T. 1979. Women at Work: The Transformation of Work and Community in Lowell, Massachusetts, 1826-1860. New York: Columbia University Press.

Faggen, H. 1989. Interview by authors, 4 May.

Fink, L., and B. Greenberg. 1979. Organizing Montefiore. In Health Care in America: Essays in Social History, ed. S. Reverby and D. Rosner. Philadelphia: Temple University Press.

- 1989. Upheaval in the Quiet Zone: A History of Hospital Workers' Union Local 1199. Urbana: University of Illinois Press.

Fox, Daniel. 1986. Health Policies, Health Politics: The British and American Experience, 1911-1965. Princeton, NJ: Princeton University Press.

Greenberg, S. 1961. Crisis in the Hospitals. The Progressive (May): 33.

Klem, M. Prepayment Medical Care Organizations. Memorandum 55, Bureau of Research and Statistics, U.S. Social Security Board. Washington, DC: U.S. Government Printing Office.

Klem, M., and M. McKiever. 1953. Management and Union Health Programs. U.S. Department of Health, Education, and Welfare Public Health Service Bulletin 329. Washington, DC: U.S. Government Printing Office.

Law, S. 1974. Blue Cross: What Went Wrong? New Haven, CT: Yale University Press.

Los Angeles Times. 1989. Phone Strike Centered on Issue of Health Care, 9 August, p. 1.

Mannix, J. n.d. Interview by Lewis Weeks. Transcript in Michigan Blue Cross Archive, Empire Blue Cross and Blue Shield Archives, New York.

Markowitz, G., and D. Rosner, eds. 1987. Slaves of the Depression: Workers' Letters about Life on the Job. Ithaca, NY: Cornell University Press.

Mills. S. 1943. Letter to L. Pink 16 March. Pink Papers, Empire Blue Cross and Blue Shield Archives, New York.

Montgomery, D. 1987. The Fall of the House of Labor. New York: Cambridge University Press.

New York Times. 1947. 2 April, p. 16.

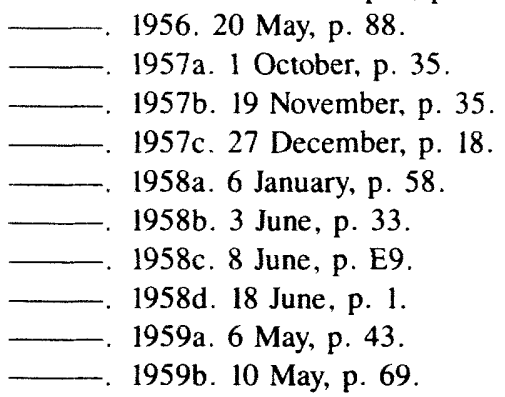




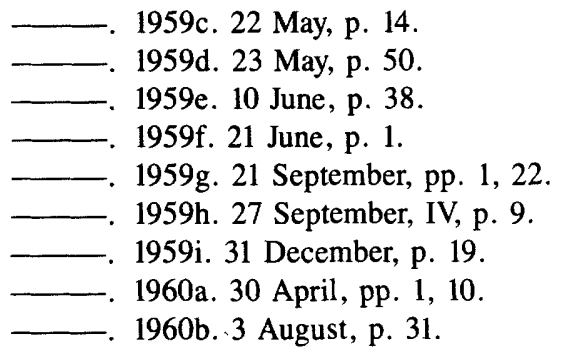

Pink, L. 1946. New York Blue Cross Sets Pace for Employer-Union Cooperation. Address before Hospital Association of New York State, 11 June. Pink Papers, Empire Blue Cross and Blue Shield Archives, New York.

Reed, L. 1947. Blue Cross and Medical Service Plans. Washington, DC: U.S. Government Printing Office.

Rosner, D., and G. Markowitz. 1985. The Early Movement for Occupational Safety and Health. In Sickness and Health in America, ed. J. Leavitt and R. Numbers. Madison: University of Wisconsin Press.

Shefter, M. 1986. Political Incorporation and the Extrusion of the Left: The Insertion of Social Forces into American Politics. In Studies in American Political Development, vol. 1.

Shurtleff, J. L. 1975. Review of Sylvia A. Law, Blue Cross: What Went Wrong? Hofstra Law Review 3: 211-36.

Shurtleff, J. L., and B. Cohan. 1989. Interview by G. Markowitz and D. Rosner, New York, 31 May.

Starr, P. 1982. The Social Transformation of American Medicine. New York: Basic Books.

Stevens, B. 1985. New Ties That Bind: The Development of Employer-Sponsored Welfare Benefits. Paper presented at the American Sociological Association Meeting, Washington, DC, 26-30 August.

Stevens, R. 1989. In Sickness and in Wealth: American Hospitals in the Twentieth Century. New York: Basic Books.

The Survey. 1910. A Strike for Clean Bread, 18 June (No. 24), pp. 483-88.

Sydenstricker, E. 1917. Existing Agencies for Health Insurance in the United States. Department of Labor, Bureau of Labor Statistics Bulletin 212 (June). Washington, DC: U.S. Government Printing Office.

Tilove, R. [1950]. Recent Trends in Health and Welfare Plans. In Proceedings of New York University Third Annual Conference on Labor. New York: New York University.

Trauner, J. B. 1977. From Benevolence to Negotiation: Prepaid Health Care in San Francisco, 1850-1950. Ph.D. dissertation, University of California, San Francisco.

Wall Street Journal. 1989a. Facing off over Health Care Benefits, 11 August, p. B1. A3. 


\section{Journal of Health Politics, Policy and Law}

Wolinsky, O. 1946. Letter to L. Pink, 17 June. Pink Papers, Empire Blue Cross and Blue Shield Archives, New York.

The Women's Label League Journal. 1913. Investigations Have Disclosed the Fact That Unhealthy and Poisonous Bread Is Made in Non-Union Bake Shops, June, p. 13. 